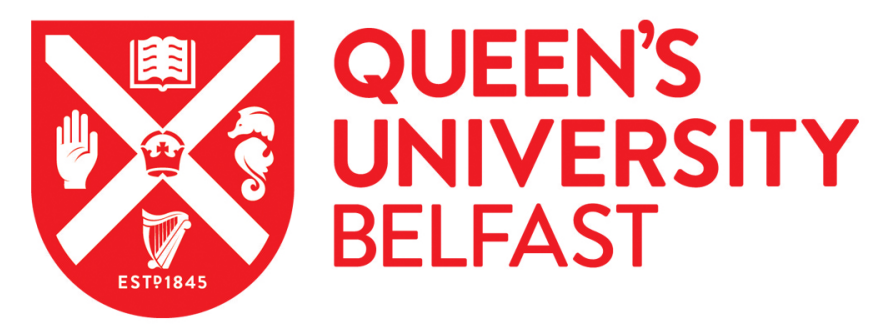

\title{
In the Aftermath of Truth: Implementing Truth Commissions' Recommendations on Reparations - Following Through for Victims
}

Moffett, L. (Accepted/In press). In the Aftermath of Truth: Implementing Truth Commissions' Recommendations on Reparations - Following Through for Victims. In The Global Legacy of Truth Commissions Intersentia.

\section{Published in:}

The Global Legacy of Truth Commissions

\section{Document Version:}

Peer reviewed version

Queen's University Belfast - Research Portal:

Link to publication record in Queen's University Belfast Research Portal

\section{Publisher rights}

Copyright 2018 Intersentia Cambridge. This work is made available online in accordance with the publisher's policies. Please refer to any applicable terms of use of the publisher.

\section{General rights}

Copyright for the publications made accessible via the Queen's University Belfast Research Portal is retained by the author(s) and / or other copyright owners and it is a condition of accessing these publications that users recognise and abide by the legal requirements associated with these rights.

\section{Take down policy}

The Research Portal is Queen's institutional repository that provides access to Queen's research output. Every effort has been made to ensure that content in the Research Portal does not infringe any person's rights, or applicable UK laws. If you discover content in the Research Portal that you believe breaches copyright or violates any law, please contact openaccess@qub.ac.uk. 


\section{In the Aftermath of Truth: Implementing Truth Commissions' Recommendations on Reparations - Following Through for Victims}

\section{Introduction}

Transitional justice emerged after the Second World War as a set of discrete measures, such as trials, truth commissions or reparations, to address the atrocities of a past regime and to transition societies away from the recurrence of atrocities. ${ }^{1}$ Since the 1990s there has been an increasing emphasis on the need for multi-faceted, comprehensive transitional justice measures to effectively deal with impunity and the consequences of mass violence. 2 It is no longer considered effective to pigeonhole discrete transitional justice mechanisms. Instead there is increasing discussion on a comprehensive package of measures that complement each other. Each of the areas of transitional justice of truth, justice, reparations, amnesties, guarantees of nonrecurrence and to a certain extent Demobilisation, Disarmament and Reintegration (DDR), have their own particular focus, benefits and limitations. Although such measures can be complementary there can also be overlap and tension between them, such as when trying to carrying out prosecutions while at the same time seeking to secure truth, which requires careful crafting of social, political, economic and legal factors to avoid derailing the transition itself.

Given that the focus of this paper is on truth commissions and reparations, it will mainly address the connection between these two measures. 3 Truth commissions and reparations, to a certain extent, have a symbiotic relationship through which they can complement and reinforce one and other's goals in acknowledging the atrocities of the past, building social inclusion and trying to vindicate victims' suffering.4 The first part of this chapter explores the bond between these two mechanisms, drawing upon different examples of how recommendations for reparations are constructed by truth commissions and their justification. The second part of this chapter analyses the

1 R. TEITEL, Transitional Justice Genealogy, Harvard Human Rights Journal, 16(1) (2003), 69-94.

2 E/CN.4/2004/88, para.10.

3 That said there is emerging practice of reparations to be connected to trials for international crimes, as well as with amnesties (such as with the Kenyan TJRC Act, Article 41), but this latter connection is often associated with impunity and reparations being perceived as 'blood money', see C. MOON, “'Who'll Pay Reparations on My Soul?' Compensation, Social Control and Social Suffering', Social and Legal Studies 21(2) (2012) 187-199.

4 D. ORENTLICHER, 2004, Independent study on best practices, including recommendations, to assist states in strengthening their domestic capacity to combat all aspects of impunity, para.59. 
implementation of reparation recommendations, finding that in most cases, states fail to follow through, or only do so where they are forced by civil society through legal and political pressure. The third part of this chapter briefly discusses transitional societies where reparations are made without a truth commission and their impact on the transition, before reaching a conclusion. It is more likely than not that truth commissions can facilitate the implementation of reparations. That said, transitional societies are complex and fragile, which cannot be easily socially engineered, the past is often still contested and fought through political and legal foras. Truth commissions can at least assuage these contests by shaking society awake to the atrocities of the past and morally motivating them to alleviate the consequences of those victims left to bear the burden of the past.

\section{The Bond between Reparations and Truth Commissions}

Reparations are intended to acknowledge and alleviate the suffering of victims. Truth commissions are established to recognise 'victims as rights holders, fostered civic trust, and contributed to strengthening the rule of law.' 5 There is some conceptual overlap between the two, with truth recovery seen as an important part of measures of satisfaction in publicising victims' experience, vindicating the wrongfulness of their suffering and identifying the institutions and actors responsible. 6 There may be challenges on implementation of reparations where truth commissions are broadly construed to include a range of historic victims, discussed further below. Truth commissions can catalyse societies' attention to victims' suffering and ongoing destitution, that in turn build 'political and public support for the government to respond positively.'7 At the other end of the spectrum reparations cannot deliver the wider social and public conversation and confrontation with the past that a truth commission can catalyse. As Verdeja finds reparations 'can only assist, not generate or sustain, a critical reappraisal of the past'.8 Accordingly, reparations and truth commissions can complement each other. A truth commission can be crucial for 'even if implicitly, acknowledging some form of collective responsibility towards the

$5 \mathrm{~A} / \mathrm{HRC} / 24 / 42$, para.24.

6 M. LAWRY-WHITE, 'The Reparative Effect of Truth Seeking in Transitional Justice', International and Comparative Law Quarterly 64(1) (2015), at 141-177, p145.

7 P. HAYNER, Unspeakable Truths: Transitional Justice and the Challenge of Truth Commissions, Routledge (2010), p163.

8 E. VERDEJA, 'A Normative Theory of Reparations in Transitional Democracies', Metaphilosophy 37(3-4), July 2006, 449-469, p460. 
victims.'9 Furthermore, reparations can be a substantive way to cement the work of a commission in alleviating the consequences of suffering for those most directly affected: the victims.

Truth commissions often make recommendations for reparations, which have now become a 'staple' of such commissions.10 Freeman and Wiebelhaus-Brahm both in part define truth commissions by their ability to make recommendations on redress for victims.11 Some peace agreements and legislation establishing truth commissions can specifically provide for reparations to be part of the commission's mandate. Others can be more ambiguous, such as the Sierra Leone Truth and Reconciliation Commission Act provides that its object is, "to address impunity, to respond to the needs of the victims, to promote healing and reconciliation and to prevent a repetition of the violations and abuses suffered.' 12 The Democratic Republic of Congo (DRC) truth commission had the power to arrange settlements for compensation and restitution, or traditional forms of reconciliation between victimised communities and perpetrators, but it was never operationalised.13 Divergences exist in the scope and complexity of reparations being proposed, from simply suggesting compensation or vague measures of reconciliation, 14 to a range of monetary and symbolic measures directed at different types of victims.

For instance the Kenyan Truth, Justice and Reconciliation Commission (TJRC) categorised and prioritised victims to concentrate resources on those most vulnerable.15 The Commission organised victims of gross violations of human rights into the following categories: (1) violations of the right to life; (2) violations to the right to personal integrity, including sexual or gender based violence; (3) forcible transfer of populations; (4) historical and contemporary land injustices; and (5) systematic marginalisation. The TJRC prioritised victims in categories 1 and 2 as

\footnotetext{
9 R. DUDAI, '"Rescues for Humanity": Rescuers, Mass Atrocities, and Transitional Justice', Human Rights Quarterly, 34(1) (2012), at 1-38, p27

$10 \mathrm{~A} / \mathrm{HRC} / 24 / 42$, para.43.

11 M. FREEMAN, Truth Commissions and Procedural Fairness, CUP (2006), p18; and E. WIEBELHAUS-BRAHM, Truth Commissions and Transitional Societies: The Impact on Human Rights and Democracy, Routledge (2010), p4. In contrast Hayner does not include recommendations for reparations as part of their definition. HAYNER, p12.

12 Article 6(1), The Truth and Reconciliation Commission Act 2000.

13 Articles 41 et 42, Loi N\%/04/018 du 30 Juillet 2004 Portant Organisation, Attributions et Fonctionnement de la Commission Verite et Reconciliation; and Hayner p253.

14 See CONADEP Argentina.

15 TRJC Report Volume IV, p97-122.
} 
those most vulnerable under the heading of Priority A.16 The victims in this group would be eligible for monetary compensation via a ten year annual pension, as well as medical and psychological vouchers for rehabilitation. Under the TJRC's reparation recommendations, all victims in the five categories are entitled to collective reparations, with other victims in Priority B only able to claim collective reparations. These collective reparations are to address the "policies and practices that negatives impacted entire groups of people', 17 and include measures such as apologies, memorials, and land restitution.18 The purpose of these collective reparations is to recognise victims' experiences, acknowledge the state's responsibility, restore their dignity and ensure non-recurrence.19 Despite being well thought out and innovative, none of these measures were ever implemented.

Reparations can also be justified to promote reconciliation, reflecting a dual political and transactional role: to recognise victims suffering, affirm their rights as citizens through social inclusion and rebuild trust in state institutions, while at the same time aiming to minimise perceptions that combatants or perpetrators are benefiting from the peace more than victims. 20 The Peruvian Truth and Reconciliation Commission (CVR) justified reparation as 'a gesture and an action that recognizes and reaffirms the dignity and status of people. Coming from the State is an expression of due respect to their status as citizens.'21 Timor Leste prioritised the issue of reparations for victims from the wider impact on Timorese societies as 'All East Timorese people have been touched and victimised by the conflict in one way or another. ... We are all victims but not all victims are equal. We must acknowledge this reality and lend a hand to those who are most vulnerable.'22 It went on to distinguish reparations as a 'form of justice is delivered which directly benefits the victim and will contribute to healing, national reconciliation and a further reduction in the possibility of violence. The most vulnerable victims of past atrocities

\footnotetext{
16 This included those in category 3 who had died as a result of displacement. 17 TRJC Report Volume IV, p107.

18 Ibid., p108.

19 Ibid., p114.

20 Sierra Leone TRC, Chapter 7, para.10-11; Chega! Timor Leste Commission for Reception, Truth and Reconciliation (CAVR) (2005), Part 11, p36. See P. HAZAN, 'Measuring the impact of punishment and forgiveness: a framework for evaluating transitional justice, International Review of the Red Cross, 88(861) 19-47 (2006), p44.

21 Vol.9, p141.

22 Chega p35.
} 
will be afforded recognition and the means to enjoy their fundamental rights and fulfil their potential on an equal footing with other citizens of Timor-Leste.'23

The Sierra Leone TRC conceptualised reparations as forming part of a 'restorative system of justice' that also includes 'accountability, truth telling, [and] acknowledgement'.24 Moreover the implementation of reparations would be 'vital to the reconciliation process because it has the potential to assist those victims whose lives have been most devastated' and to help 'to facilitate relations between victims and perpetrators.'25 The Kenyan TJRC Act, defines reparation as 'means dignifying the victims by measures that will alleviate their suffering, compensate their social, moral and material losses, restitute their rights' 26 The Argentinean CONADEP framed reparations along the lines of truth that 'The first indispensable reparation demanded by society after fundamental institutions had been restored was to ascertain the truth of what had happened, to 'face up' to the immediate past and let the country judge.'27 Its recommendations with regards to reparations were quite general, including that 'appropriate laws be passed to provide the children and/or relatives of the disappeared with economic assistance, study grants, social security and employment and, at the same time, to authorize measures considered necessary to alleviate the many and varied family and social problems caused by the disappearances.'28

Reparations are not only recommended by official truth commissions, but also 'unofficial' 29 truth recovery initiatives by civil society in the face of state impassivity. In Sierra Leone before the war chiefs played an important role in the community in mediating disputes through compensation between aggrieved party and the wrongdoer, which became a source of grievance when it was used for extortion. As a result the community truth initiative of Fambul Tok does not use compensation in its reconciliation committee meetings between victims and perpetrators.30 In Zimbabwe

\footnotetext{
23 Chega p36.

24 Volume 3(B), Chapter 7, para.8

25 Chapter 7, para.9.

26 Article 2(1), The Truth, Justice and Reconciliation Commission Act No. 6 of 2008.

27 Nunca Más (Never Again): A Report by Argentina's National Commission on Disappeared People, London: Faber \& Faber, 1986, Part IV.

28 Part VI, Recommendation C. Along with guarantees of non-repetition such as human rights training for the military, strengthen investigations of human rights violations and the adherence to such rights.

2928 August 2013, A/HRC/24/42, para.21

30 Fambul Tok International, Community Healing in Sierra Leone, and the World - Our Second Year, (2010), p23.
} 
the Breaking the Silence report did not recommend compensation, but instead the recovery of the remains of those disappeared, and symbolic shrines of those disappeared to publicise in social memory of clandestine disappearances. 31 Importantly, the report noted that while there was a War Victims Compensation Act that would need to be amended, providing compensation to each individual victim would be impossible as too much time had lapsed, most of the evidence of abuses has been destroyed, and the sheer scale of violations would leave the state paying out hundreds of millions of dollars.32

In Guatemala the Recuperacion de la Memoria Historia (REMHI) report recommendations were aimed at a range of actors, including the guerrillas, the Church, and the international community. It recommended reparations on the basis that 'the state has the obligation to adopt measures that help compensate some of these losses and that those groups who were affected by the violence can live with dignity.'33 It recommended 'economic reparations or development projects, grants and study programmes, commemorations and monuments, and psychosocial projects for the victims and survivor.' These were similar to the official CEH commission recommendations. 34 Isaacs notes that the official and unofficial commission failed to make their recommendations 'stick' as acknowledging genocide was continually debated in formulating the reparations programme. 35 Other unofficial truth commissions, such as the Brazilian Nunca Mas report, SERPAJ and Ardoyne are more concerned with documenting and mapping out human rights violations, rather than making recommendations. Reparations require substantial financial commitment, which unofficial truth commissions would struggle to mobilise and administer. Even if unofficial truth commissions could somehow gather sufficient resources for reparations, they would be missing an important component of the official acknowledgment of the victims' harm, and risk being seen as charity rather than

31 Breaking the Silence: Building True Peace, A Report on the Disturbances in Matabeleland and the Midlands 1980 to 1988, (1997), The Catholic Commission for Justice and Peace in Zimbabwe and The Legal Resources Foundation, p205, 211-212. It also recommended psychological rehabilitation for affected communities and human rights violators as well as community development.

32 Ibid. p212.

33 REMHI report, Tomo IV.

34 Guatemala: Memory of Silence, Report of the Commission for Historical Clarification, Conclusions and Recommendations, (1999), p49-54.

35 A. ISAACS, 'Truth and the Challenge of Reconciliation in Guatemala', J. Quinn (ed) Reconciliation(s): Transitional Justice in Postconflict Societies, McGill-Queen's University Press, (2009) at 116-146, p140. 
vindication of victims' rights and social inclusion.36 Nonetheless, Bickford suggests that unofficial truth commissions can stimulate debate and dialogue around the importance of reparations, such as the REMHI in Guatemala.37

It is clear from these examples that recommendations and justifications for reparations by truth commissions are varied in their scope and detail. Across the globe there remain close natural connections between uncovering the truth and remedying individuals' harm. That said, each context has its own idiosyncrasies that must be taken into account. These can include cultural or religious dimensions to dealing with the past (such as Ubuntu in the South African TRC), traditional or indigenous practices, or existing reparation programmes. Given the numerous variables in a society and that transitional justice is not an exact science to simply apply to each data set that will ensure consistency in results. However, there may be merit in the field of transitional justice outlining principles and standards of measures such as reparations, to give them increased legitimacy when they are domestically recommended by truth commissions. Human rights bodies have been important in this regard, in particular for reparations. ${ }^{38}$ As such, the causality between truth commissions and reparations is not examined here in a quantitative way, but rather more mid-range theorising, drawn from qualitative research. ${ }^{39}$

At best we can make broad suggestions that having a truth commission can at least open up public debate and awareness of victims' harm that gives impetus to establish reparation programmes to alleviate their suffering, or provide a basis for national and international civil and criminal litigation for reparations. Official and unofficial truth commissions make similar assumptions that reparations are connected or at least part of a continuum of necessary measures society needs to address to move forward. Together these measures suggest both a corrective justice approach for individual victims, as well as broad societal transformation, in particular with the role of guarantees of non-repetition and truth itself as having reparative value to acknowledge the past and contribute to reconciliation. This reparative value of truth is

36 L. BICKFORD, 'Unofficial Truth Projects', Human Rights Quarterly 29(4) (2007) 994-1035, p996. 37 Bickford ibid., p1031.

${ }^{38}$ See C. SANDOVAL, 'Two steps forward, one step back: Reflections on the jurisprudential turn of the Inter-American Court of Human Rights on domestic reparation programmes', The International Journal of Human Rights (2017) 1-17.

${ }^{39}$ R. K. MERTON, 'On Sociological Theories of the Middle Range' in R.K. Merton (ed.), Social Theory and Social Structure (The FreePress 1949) 39-53. 
key for unofficial truth commissions, but their informality may lose the effect of acknowledgement and reparation where it is not coming from an authoritative responsible actor.

Olsen et al find that acknowledgment of violations through a public truth commission, and reparations for such crimes, can reinforce accountability.40 This does not always follow. Truth commissions can make dealing with the past toxic, poisoning the discussion on reparations and paralysing momentum for its implementation. In Northern Ireland, the recommendation of a 'recognition payment' for all bereaved families by the Consultative Group on the Past, a public consultation group working around the establishment of a truth commission, after protests on this provision it resulted in the whole scheme being eventually shelved by the government, due to the moral equivalence such a payment would have made between 'innocent victims' and killed combatants. 41

This makes the design of and consultation on reparations and its process a vital part of shaping measures that can adequately and appropriately respond to victims' harm. 42 Victims have varying interests that change over time, conflict and compete with each other. Victims, depending on their circumstances and harm caused to them, may prioritise truth recovery over reparations, vice-versa or seek both. Their expectations from in engaging with a truth commissions can vary from having a positive procedural experience or satisfaction at the outcomes to being vilified or frustrated by the limited scope, procedure or recommendations. ${ }^{43}$ This makes the process, design and participation of victims in truth commissions important in how it can shape the scope of the subsequent or other transitional justice measures. ${ }^{44}$

In the 2004 Valech Commission in Chile, Collins points out that where the promise of reparations was unclear, victims came forward to testify anyway. Yet other victims were discouraged from testifying, given the 50 year embargo on

40 T. D. OLSEN, Leigh A. PAYNE, Andrew G. REITER and Eric WIEBELHAUS-BRAHM, 'When Truth Commissions Improve Human Rights', International Journal of Transitional Justice, 4 (2010), at 457-476, p475.

41 See L. MOFFETT, Reparations for 'Guilty Victims': Navigating Complex Identities of VictimPerpetrators in Reparation Mechanisms, International Journal of Transitional Justice 10(1) (2016), at 146-167.

42 See C. CORREA, J. GUILLEROT and L. MAGARRELL, 'Reparations and Victim Participation: A Look at the Truth Commission Experience', in C. FERSTMAN, M. GOETZ, A. STEPHENS (Eds.), Reparations for Victims of Genocide, Crimes Against Humanity and War Crimes: Systems in Place and Systems in the Making, Martinus Nijhoff (2009) at 385-414.

${ }^{43}$ See FREEMAN.

${ }^{4}$ Ibid. 
accessing the testimony, that the exchange of reparations made some of them feel like they were being 'silenced or bought off'.45 In contrast in Peru many victims participated in the truth commission in the hope of obtaining reparations, ${ }^{46}$ though some also sought truth and justice. There is to some extent an unspoken covenant that victims coming forward to testify to truth commissions, will get more than a warm, healing feeling, which creates expectations of some form of substantive form to address their harm through reparations. 47 The failure to deliver reparations after truth commissions, whether part of its mandate or not, can only cause further distrust within a state and society that allowed these individuals to be victimised.

From a victim's perspective, testifying before a truth commission means publicly opening themselves up to a traumatic event(s) of their past. They may do this as a good citizen, or perhaps for other reasons, such as to ensure that such atrocities do not reoccur. Yet there can be a 'cost' for victims in engaging with a truth commission, such as the risk of reopening psychological wounds, or suffering secondary victimisation if they are then attacked and diminished by the state or other actors in the engagement with truth commissions or claims for reparations. As Daly points out, this may have a social cost of 'domestic violence, reduced productivity, increased substance abuse'.48 Moreover, victims' participation in a truth commission can be staged or manipulated for political ends, such as excluding victimised perpetrators or legitimise violence by state actors. 49 Truth commissions are to a certain extent dependent on victims coming forward. Without them truth commissions are limited to their own investigations, archives and secondary sources. As part of the process, psychological support and counselling is needed to minimise the harm to victims and inform their expectation. Otherwise the processes and the failure to deliver reparations will cause them secondary victimisation. If there is an 'implicit bargain' that victims testify for truth commissions in exchange for more substantive redress through reparations, the failure to implement reparation recommendations in

45 COLLINS $2016 \mathrm{p} 71$.

${ }^{46}$ L. J. LAPLANTE, 'From Theory to Practice: Implementing Reparations in Post-Truth Commission Peru', in B. R. JOHNSTON and S. SLYOMOVICS (eds.), Waging War, Making Peace: Reparations and Human Rights, Left Coast Press (2009) at 75-93, p81.

47 LAWRY-WHITE, p170.

48 DALY 441.

49 CORREA et al, p389. 
practice may be detrimental in the long run to future truth commissions, as victims appreciate the unlikelihood that such a process will provide them with redress.

There are also drawbacks in closely connecting reparations with truth commissions. There is a danger that a truth commission will close the book on the past through a narrowly constructed mandate (temporal, territorial, violations),50 not naming of names,51 or sealing information for decades.52 These issues can have a detrimental effect on the scope of truth and acknowledgement, but also the extent of reparations. For instance in South Africa, the TRC recommended reparations only for those victims of the four categories of human rights violation (killing, torture, severe ill-treatment and abduction) and who were found to be victims by the commission. 53 However, less than twenty-two thousand victims were recognised by the commission as being eligible, despite some South African victim groups claiming the true number of victims being over a 100,000. As a result, the recommendations and the delayed implementation of a smaller amount by the South African government left many victims feeling 'betrayed' 54 that the implementation of reparations was 'false reconciliation' or a way to buy their silence. 55

Truth commissions' recommendations and a state's implementation can feel like orchestrated top-down way by the state to draw a line on the past and for society to move on, compelling victims to accept whatever little or limited reparations that is proposed than none at all.56 Given the usually short temporal scope of truth commissions, it may just capture a snapshot of victims' current needs and harm, without encompassing something that can evolve over time, as they get older and their health and financial security deteriorate. These limitations can undermine these

50 Such as the focus on civil and political rights, rather than economic, social and cultural rights. See L. LAPLANTE, 'On the Indivisibility of Rights: Truth Commissions, Reparations and the Right to Development', Yale Human Right and Development Journal 10(1) (2007) at 141-177; and M. MAMDANI, 'Amnesty or Impunity? A Preliminary Critique of the Report of the Truth and Reconciliation Commission of South Africa (TRC)', Diacritics, 32(3-4) (2002), 33-59, p37.

51 Such as the Canadian TRC - see A. WOOLFORD, 'The healing state? Residential schools and reparations in Canada', in J. M. WEMMERS, Reparation for Victims of Crimes against Humanity The healing role of reparation, Routledge (2014), at 126-142, p133

52 Chile, see COLLINS 2016.

53 Vol.5 Chapter 5 , p176.

54 T. MADLINGOZI, 'On Transitional Justice Entrepreneurs and the Production of Victims', Journal of Human Rights Practice 2(2) (2010) 208-228, p215.

55 B. HAMBER, 'The Dilemmas of Reparations: In Search of a Process-Driven Approach', in K. De FEYTER, S. PARMENTIER, M. BOSSUYT and P. LEMMENS (eds.), Out of the Ashes: Reparation for Victims of Gross and Systematic Human Rights Violations, at 135-149, p139.

56 HAMBER ibid., p140; and WOOLFORD p133. 
grander justifications of truth commissions, reparations and the goal of transitional justice of social inclusion, civic trust, dealing with the past to prevent its repetition, and reconciliation. Although on balance, from reviewing a number of truth commissions, reports by UN Special Rapporteurs and other qualitative research, it seems that the benefits of connecting truth commissions to reparations outweigh the risks, as can be seen in the final section discussion on countries which attempt reparations without a truth commission.

\section{Implementation of Reparation Recommendations}

In theory, reparations are designed to cement a truth commission's commitment to redressing and acknowledging the past by focusing on those who have been most affected by the violence. Yet in practice, the data on the implementation of reparation recommendations made by truth commissions is poor. Bakiner found that in analysing 15 truth commissions, only 2 states had implemented reparation recommendations by a truth commission.57 This mirrors wider trends in transitional societies where only 14 out of 84 have implemented reparation programmes.58 This reflects that when it comes to implementation, the ball is in the government's court, with reparation recommendations being 'merely potentialities' with implementation and institution reform beyond the powers and capacity of truth commissions. 59 However, it is possible discern some trends of successful, partial and forced implementation of reparation recommendations.

'Successful' implementation of reparation can be defined as where subsequent bodies are established, and deliver monetary and symbolic measures. This does not require a 'mirror image' approach, where recommendations have to be directly implemented word for word, but that there is a margin of appreciation in implementing such measures to reflect the democratic process will modify the legislation of such provisions. What is important for a successful implementation is that it includes the majority of serious violations, munificence in the range of measures and mostly satisfies victims' expectation of remedy of their harm. Ideally this should be done in a timely manner to mitigate any further harm to victims. With this in mind, we can say that often more work is required by the government to work

57 See O. BAKINER, 'Truth Commission Impact: An Assessment of How Commissions Influence Politics and Society', International Journal of Transitional Justice 8(1) (2014) 6-30, p18.

58 Olsen et al., p53.

$59 \mathrm{~A} / \mathrm{HRC} / 24 / 42$, para.38. 
out the complex procedures in designing and implementing reparations from a truth commission's recommendations. Procedures such as drafting legislation, a victim registry and inter-institution cooperation can be planned from an early stage of the truth commission, factoring in their administration and funding, with recommendations and consultations with victims tailoring the appropriate measures and eligible beneficiaries

The two successful examples identified by Bakiner (Chile and Sri Lanka) were planned as part and parcel of the measures of the transition. For instance, Ferrara points out that the success of reparation being implemented in Chile to those who had been extra-judicially executed was down to reparations and the truth commission being viewed as the two 'main pillars' of the political transition.60 Often seeing reparations delivered comes down to political will of the government to honour the recommendations of the truth commission. It may be that a truth commission's recommendation that reparations fail to engage with political, social or economic realities, and as such there is an art in making reparation recommendations 'policy friendly'.61 In Sri Lanka, reparation recommendations were provided through already existing reparation bodies, such as REPPIA. 62

Some truth commissions can provide detailed recommendations on what reparations should look like, thereby helping to minimise the policy and legislative work required of the government in order to obtain successful implementation. The 2007 Ecuadorian truth commission in its recommendations provided a draft reparations law, which was later enacted into law.63 The intention of the commission was to help ensure that reparations were implemented, after examining other countries where reparation recommendations were often left unfulfilled.64 The legislation itself mirrors the recommendations of the truth commission, such as its purpose and temporal scope. It is of course not an exact implementation, issues such as interpretation in good faith in the victim's benefit do not appear in the passed law, and the legislation dilutes certain provisions such as scholarships, as recommended by the

\footnotetext{
60 FERRARA p65.

$61 \mathrm{~A} / \mathrm{HRC} / 24 / 42$, para.72.

62 Rehabilitation of Persons, Properties and Industries Authority, Legislative Act No. 29, 2 June 1987.

63 Informe de la Comisión de la Verdad Ecuador 2010, Tomo 5: Conclusiones y recomendaciones, p395-413. Ley Reparacion Victimas Judicializacion Violaciones Derechos Humanos, 5 diciembre 2013, Oficio No. SAN-2013-1642

64 Ibid, p361.
} 
commission, which became training and advice on developing economic inclusion initiatives.65 Nonetheless a provision in the legislation speaks of the importance of truth and reparations being complementary and inseparable to prevent the repetition of such violations. 66

Some truth commissions' recommendations cannot be implemented because they are too unrealistic or too vague, making it difficult to discern if its requirements have been met. For instance, the South African TRC had over a hundred recommendations, mostly aimed at the government, but also included civil society such as the media, faith communities and businesses.67 The scale of reparations required may take time to implement in practice, and having numerous reparation recommendation may require a staggered approach, prioritising measures to those most vulnerable. In Peru, despite the CVR recommending a range of reparations, collective measures for affected communities only began in 2006 and compensation in 2011, which were rushed around the time of an election 68 and required implementation across different ministries and agencies (education, health, social welfare) in the Peruvian context was 'uneven and slow'.69

There is a danger that truth commissions can be too prescriptive in their design of reparations recommendations, such as where they are too specific in terms of the regulations of the operation of a reparation programme, which is best settled by a reparations body itself. Where truth commissions provide specific amount of compensation these might be worthless in the years it takes for them to be implemented. This was the case in Ghana, where its high inflationary economy devalued the specific amounts set out for each type of violation by the National Reconciliation Commission, which trivialised victims' harm and created a hierarchy of victimhood.70 Truth commissions' recommendations have to be implemented through democratic processes such as parliaments. During such processes, a truth commission's findings can be dissected in terms of the scope of reparations or eligibility, such as drawing a line between victims and perpetrators or for one side to

65 Artículo 6(5).

66 Preamble, para.5.

67 Vol. 5 chapter 8, p308.

68 CORREA p15-16.

69 CORREA $2013 \mathrm{p} 21$.

70 VALJI, p23. 
'blame' the other.71 The recommendations of truth commissions are best situated in tracing out the principles and shape of reparations based on victims who have testified before it and other evidence, such as draft legislation and eligible victims, but a reparation programmes should be based on wider research and victim engagement by itself, guided by expertise on reparations and responding to victims' harm.

Truth commissions can carefully consider the financial and social implications of reparation recommendations and the challenges of implementation. The Peruvian CVR acknowledged that no matter what it proposed in terms of reparations, it was dependent on political will, resulting in it developing a detail reparations policy.72 In the case of the Sierra Leone TRC, it recommended social services rather than individual compensation, given victims' views to the commission, but also to make such measures 'feasible and practical as possible' given the resources available to the state.73 Moreover, due to the widespread poverty caused as a result of the conflict, awarding individual cash payments in Sierra Leone could have potentially 'lead to additional division and strife as opposed to the sense of social solidarity that the reparations programme is meant to foster.'74 Similarly the Kenyan TJRC provided detailed recommendations for reparations with the intention that they would be 'practical and implementable'.75 Hayner notes that truth commissions often aim to be 'realistic and policy-relevant' to ensure that their recommendations have the best chance of being implemented. 76 Despite this, the Sierra Leone and Kenyan commissions' recommendations have not yet been put into action. In Sierra Leone, interim reparations were made to some victims through funding through international donors, in contrast to the more substantial financial support given to ex-combatants under demobilisation and reintegration programmes. 77

71 See C. LAWTHER, Truth, Denial and Transition: Northern Ireland and the Contested Past, Routledge (2014).

72 See J. GARCIA-GODOS, 'Victim Reparations in the Peruvian Truth Commission and the Challenge of Historical Interpretation', International Journal of Transitional Justice 2(1) (2008) 63-82, p74.

73 Chapter IV, para. 71.

74 Ibid.

75 Kenyan TJRC Vol. IV, p98.

76 HAYNER, p163.

77E. CONTEH and M. BERGHS, 'Mi At Don Poil': A Report on Reparations in Sierra Leone for Amputee and War-Wounded People, Amputee and War-Wounded Association, Freetown, Sierra Leone (2014), p6. 
Truth commissions have also been conscious that victims' needs change over time, such as recommending pensions for those who are injured.78 Those victims coming before a commission may emphasise the need for assistance over more substantive long-term reparations, such as access to healthcare, education and housing. 79 Waldorf suggests that victims were unsatisfied with the traditional reparations approach which would return them to the status quo ante.80 However, while victims coming before the Sierra Leone TRC did not prioritise compensation, in Ghana, 9 out of 10 victims who appeared before the commission (some 2,000) did so to seek compensation.81 Victims' interests should not all be reductively merged into what the majority wants or needs. Victims of extra-judicial executions can have differing needs from families of those disappeared, and those who have been seriously injured or tortured have distinct needs and from those of sexual violence or child soldiers. Reparations are intended to acknowledge and alleviate those who suffer the most, with assistance aimed at helping the recovery of the generally affected population. With the passage of time, victims' needs may move on from immediate assistance to support themselves to more substantive reparations to seek acknowledgement and alleviation of their long term suffering.

Timing can play an important part in the implementation or sequencing of transitional justice mechanisms, such as truth commission and reparations. Collins suggests a 'phased' approach to transitional justice. Instead of trying to do all transitional justice measures at once, she suggests that a more 'progressive realisation' can enable states to build momentum for transitional justice with measures that 'generates least internal resistance.' 82 Hayner suggests that in some countries, reparations have come in waves on the back of truth commissions or litigation at regional courts, such as in Chile and Argentina.83 Firchow calls for greater research into the sequencing between reparations and reconciliation that can facilitate the community acceptance of reparations to victims, and repair the social

78 Sierra Leone TRC, paras.71 and 168-171. South African TRC Volume Five, para.41.

79 Of the 7,707 victims who testified before the Sierra Leone TRC, 49\% sought home or shelter, $41 \%$ education, $27 \%$ health care and $18 \%$ cash- reflecting more than one measure by respondents, Chapter IV, para.30 figure 1. See also in Peru, LAPLANTE, 2008 p351-352.

80 L. WALDORF, 'Anticipating the Past: Transitional Justice and Socio-Economic Wrongs', Social and Legal Studies, 21(2) 171-186, p178.

81 N. VALJI, Ghana's National Reconciliation Commission: A Comparative Assessment, ICTJ 2006, $\mathrm{p} 22$.

82 COLLINS 2016 p79.

83 HAYNER p170-171. 
fabric of communities.84 More broadly timing is a key debate in transitional justice and its wider engagement with rule of law initiatives, development, democratisation 85 and reconciliation. However, kicking the issue of reparations down the road may mean that the momentum for delivery is lost when all the energy is place on a truth commission. Hamber notes that the South African government failed to deliver symbolic reparations early on in the transition at a time when it would have been more receptive to their delivery.86 The difficulty with reparations is that it requires a mapping out of the universe of victims and creating at least a registry of those who have suffered and would be eligible, through legal and evidential requirements. Such programmes require time and resources to set up so that they deliver measures that are not merely symbolic, but are fair and efficient. Nevertheless, the sooner evidence and documentation of violations can be collected, the more quickly the victims' harm can be alleviated, as well as ensuring that their harm does not develop into long term vulnerability and marginalisation.

\section{Challenges to Implementation}

Reparations carry baggage that even the most carefully crafted recommendation from a truth commission can easily falter in the face of political contention or intransigence over such issues as who is seen as a deserving victim worth of redress. In Peru, despite the CVR recommendation of an inclusive approach to reparations that encompassed victimised non-state actors, the issue became polemic as the government initially dragged its feet on implementation, prioritising redress for wounded government soldiers and screening measures to exclude members of the Shining Path that increased the evidential burden of victims in claiming reparations. 87 Similarly in South Africa, victims were tarred by the government as being economic opportunists in their claims for the TRC's reparation recommendations to be implemented. 88

84 P. FIRCHOW, Do Reparations Repair Relationships? Setting the Stage for Reconciliation in Colombia, International Journal of Transitional Justice 11(2) (2017), 315-338, p331.

85 See L. E. FLETCHER, H. M. WEINSTEIN and J. ROWEN, Context, 'Timing and the Dynamics of Transitional Justice: A Historical Perspective’, Human Rights Quarterly 31 (2009), 163-220, p218-219. 86 HAMBER 2005 p147.

87 L. J. LAPLANTE, 'From Theory to Practice: Implementing Reparations in Post-Truth Commission Peru', 75-93, p87.

88 O. MAKHALEMELE, 'Still not Talking: The South African Government's Exclusive Reparations Policy and the Impact of the R30,000 Financial Reparations on Survivors', in FERSTMAN et al., 541$566, \mathrm{p} 547$. 
The lack of implementation is often due to a lack of political will on the part of the government, which after an authoritarian regime or post-conflict is still struggling with the political, social and economic costs of the past. In some cases the final reports of a truth commission are delayed (e.g. the 1986 Ugandan truth commission report was only released in 1994) or sealed, such as in the 1974 Uganda Commission of Inquiry into Disappearances. 89 In Peru, while reparations were eventually given, the years of delays around individual awards (over eight years) left victim feeling 'disillusioned and cynical' about the truth commission, 'nullifying [its] positive results' and the government's commitment to redressing their suffering.90 Political will can only take an implementation process so far. As acknowledged by the OHCHR, implementation is a major challenge, which also requires 'sufficient institutional capacity' and funds to undertake these measures.91 As such, donors and international organisations can play an important role in the delivery of reparations, helping to fill in these gaps in resources, but also in how they prioritise funding and development goals in shaping values in transitional societies. In such cases where the state has limited resources and is dependent on donors in the short term, the government can still play an important role to play in acknowledging its responsibility for violations and ownership in delivering redress to all victims of the violence.

In the face of elections, waning public support or interest in the transition, even force majeur 92 or unforeseen crises can deprioritise reparations, such as an economic slump (Argentina and Ghana) or natural disasters (Haiti and Nepal), can diminish the political impetus for seeing recommendation for reparations implemented. However, if there is a will, there is a way, and there are many avenues to fund reparations, whether through 'wealth taxes', 93 seizing the assets of

89 This report has still not been official published, but a leaked version is available online, where the commission recommends reparations including compensation for illegally detained prisoners, restitution of property of disappeared soldiers, and social services to widows and children of those disappeared. 1974 Commission of Inquiry into the Disappearances of People in Uganda since 25 January 1971. Available at USIP https://www.usip.org/index.php/publications/1974/06/truthcommission-uganda-74 p789-800.

90 L. LAPLANTE and K. THEIDON, 'Truth with Consequences: Justice and Reparations in PostTruth Commission Peru', Human Rights Quarterly 29(1) (2007) 228-250, p231 and p248; and similarly in South Africa - HAMBER, Out of the Ashes, 135-149, p144. The delay in Peru was over who should be eligible (i.e. to exclude injured guerillas) the evidential requirements imposed on victims, and the procedure and forms of reparations.

91 Rule-of-law. Tools for Post-conflict States: Truth Commissions, Office of the United Nations High Commissioner for Human Rights 2006, p31.

92 Acts of God.

93 SATRC, Vol. V, Chapter 8, p319. 
perpetrators, donor contributions, issuing government bonds, or levies on natural resources. 94 That said reparation programmes can often be long term financial commitments that need to have a dedicated budget line in a government's expenditure to make them meaningful and effective, even if the amounts will taper off in time. ${ }^{95}$

Implementation can be delayed or derailed by the politics of reparations. Opposition parties or members of the former regime can use the political nature of reparations and any controversy associated with them, such as economic cost, corruption or benefiting victim-perpetrators, to weaken the political power of the government and its vision of transition. Successive governments or legislative bodies may try to 'ignore, evade and delay' if it does suit their political ambitions or benefit their constituents. 96 For truth commissions which take years, it can mean that recommendations get caught in election cycles with victims and reparations used as 'political footballs'.97 This can leave societies with 'partial implementation', in that some recommendations are delivered by the government, but not to the scale, intent or design of the truth commission, such as in South Africa where a fraction of the recommended amount of reparations was distributed to victims. 98

\section{Partial Implementation}

In practical terms, reparation programmes require substantial resources and administration to deliver successfully. This can mean that progressive recommendations by a truth commission on reparations may only be partially met by the government, in the short and medium term after mass violence, due to other reconstruction needs. There is a role for international community and international or regional actors to help build capacity and assist in the delivery of reparations, such as the International Organisation for Migration's support of the Sierra Leone reparation programme or the work of the International Committee of the Red Cross (ICRC) in recovery of the disappeared alongside national NGOs in Guatemala. Within a country public, political and media attention to victims can fade, reducing the impetus to

\footnotetext{
94 Sierra Leone - Lomé Agreement.

${ }^{95}$ See P. de GREIFF, Reparations: Report by the Special Rapporteur on the promotion of truth, justice, reparation and guarantees of non-recurrence, 8 October 2014, A/69/518, para.56.

96 WALDORF, p177.

97 P. GALLAGHER, 'A deflated political football: external perceptions of the campaign for a pension for those severely physically injured during the conflict in Northern Ireland', masters thesis, 2017 - on file with the author.

98 The South African TRC recommended \$2,700 for six years to 21,676 victims (\$16,200 total), but instead the government provided a single payment of $\$ 4,900$ to 17,408 victims
} 
deliver reparations to them. For instance in Ghana with the initial delay by the government in implementing reparations, where a budget was not established for reparations before the NRC report came out in 2005, despite being deferred from being published in 2004.99 The Ghanaian NRC had recommended a comprehensive reparation programme that included apologies, a memorial, monument, a national day of remembrance, restitution of property and compensation, as well as scholarships and health benefits for survivors and next of kin. Only in 2007 did the Ghanaian government pay out $\$ 1.5$ million USD in compensation to some 2,000 victims ranging from $\$ 217$ to $\$ 3,300$ based on their harm suffered, but not the more symbolic collective measures of an apology or monuments.100 Victims were dissatisfied with the same amount of compensation provided, but as Asare points out, public attention towards dealing with the past had waned.101 This reflects the challenges of trying to consult and engage victims in the design of reparation recommendations by truth commission, particularly where there are multiple types of violations, different actors involved, and a large geographical area. In such circumstances, conducting outreach and providing sufficient time to engage and build the capacity of victim groups can be challenging.102 This does not mean it should not be done, but that it needs to be considered in the design and delivery of reparation recommendations and implementation.

Implementation of reparations may also be limited by the lack of engagement shown by key actors, such as ex-combatants, in facilitating such measures. In the case of the Chile reparations based on the commission's recommendations delivered monthly pensions to some 5,794 victims, 103 but failed to discover the whereabouts of many of those disappeared due to the lack of cooperation from military personnel on the location of the victims' remains.104 Other actors may also shape the transition, such as economic forces or donors, who may be more concerned with market stabilisation and economic development than spending already limited public finances on uncovering past crimes. Yet this is short sighted, given that the failure to address

99 VALJI, p25-27.

100 A. AMPOFOA ASARE, 'The Ghanaian National Reconciliation Commission: Reparation in a Global Age', The Global South, 2(2), Fall 2008, 31-53, p35 and 49.

101 ASARE, p49.

102 CORREA et al, p393.

103 The Commission had originally identified 2,298 victims. E. LIRA, Policy for human rights violations in Chile, P. de GREIFF (2006), 55-101, p57-59.

104 FERRARA p62. 
past atrocities and causes of violence risks future conflict and marginalisation that will undermine any future development.

In the case of South Africa the lack of financial backing for community measures meant that reparations were only partial. Although the TRC recommended more substantive individual compensation that the government provided, it also viewed apartheid as a crime against humanity and that it 'constructed and destroyed' communities.105 As such, there should also be a collective and community dimension to reparations. Community focused rehabilitation sought to ensure reconciliation and transform the way in which services are provided to all South Africans, rather than being discriminatory, depending on the recipient's race.106 Yet the South African President's Fund responsible for financing these community measures has not yet disbursed these measures.107 In the face of the South African government's slow and ineffectual action, victim groups such as the Khulumani Support Group, have initiated litigation and political protests to demand reparations. In such cases where the state has not implemented or done so partially, civil society, in particular victim groups, may try to force implementation through social and political mobilisation or strategic litigation at domestic or international courts.

\section{Forced Implementation}

In some cases, there can be decades between a truth commission findings and victims receiving redress. Where reparations are delivered during such long periods, it is often only due to litigation or political mobilisation of victims, and in some cases political opportunism, as the state is approaching elections.108 Forced implementation here refers to the lack of political will of the state to implement the recommendations of a truth commission, but being compelled to do so because of domestic and/or international pressure.

There are a number of examples of reparations being delivered years after a truth commission recommends them. In the case of Chad, a truth commission was established in 1995 after Hissene Habré was deposed. It recommended reparations,

\section{MAMDANI 44.}

106 Vol. 5, Chapter 5, para.95.

107 F. COLLINS, 'R1.5-billion for apartheid victims but thousands still waiting for money', Times, 28 August 2017.

108 Such as reparations made to victims in northern Uganda in 2010 by the Uganda government before the presidential election to the victims of the Mukura massacre - Mukura Massacre of 1989, Justice and Reconciliation Project, Field Note XII, March 2011, p17. 
but victims sought justice against Habré for nearly thirty years through the International Court of Justice and then the Extraordinary African Chambers. Only in 2017 were reparations ordered, similar to the truth commission's original recommendations against Mr Habré and the Chadian government, but there have still been delays in setting up the delivery of these reparations. ${ }^{109}$ As the Habré case shows, it is also important to acknowledge the international dimensions of victims pursuing redress abroad where their government is unwilling or unable.110 This is a long and arduous process that places a heavy burden on victims to seek redress. There has been similar experiences in relation to Chile, with the arrest of former president Augusto Pinochet in London that revived the issue of dealing with the past more comprehensively. This included revisiting the scope of victims and reparations, where the Rettig commission had only examined those killed or disappeared the Valech Commission in 2004 and 2010 covered those who had been imprisoned on political grounds and tortured by the regime. 111

In Guatemala, despite reparations being outlined in the 1996 peace agreement and in the official and unofficial truth commissions, it was only because of continuing judgement of mass violations of human rights and awards of reparations to dozens and even hundreds of victims in cases at the Inter-American Court of Human Rights was a domestic reparation programme establish to reduce the cost of paying reparations to all affected victims. 112 Yet despite creating a national reparation programme, the Guatemalan government has not implemented at the time of writing in 2018 many of the collective and economic reparations to victims, such as the Plan de Sanchez and Rio Negro cases. Such a relationship between the national and international has not always been top down, but can be integrative. Generally the

\footnotetext{
109 \$148 million or 82,290,000,000 CFA Francs - Appeals Chamber of the Extraordinary African Chambers, The Prosecutor v. Hissein Habré, dispositif, 27 April 2017, p225-227. A similar ruling was made in the Chadian courts for joint liability of Mr Habré and the Chadian state - see N. ISKANDAR DIAB, 'Challenges in the Implementation of the Reparation Award against Hissein Habré: Can the Spell of Unenforceable Awards across the Globe be Broken?' Journal of International Criminal Justice 16(1) (2018) 141-163.

110 See also the South African example and the ACTA claims against corporations, see J. SARKIN, 'Pursuing Private Actors for Reparations for Human Rights Abuses Committed in Africa in the Courts of the United States of America', in C. VILLA-VICENCIO and E. DOXTADER (eds.), Reparations in South Africa, David Philip Publishers (2004), at 271-320.

111 See C. COLLINS, 'Truth-Justice-Reparations Interaction Effects in Transitional Justice Practice: The Case of the 'Valech Commission' in Chile', Journal of Latin American Studies 49 (2016) 55-82. 112 N. ROHT-ARRIAZA, 'Guatemala: Lessons for transitional justice', in C. LAWTHER, L. MOFFETT and D. JACOBS (eds.), Research Handbook on Transitional Justice, Elgar (2017) at 445$465, \mathrm{p} 449$.
} 
Inter-American Court has tried to fit victims that come before it within national reparations programmes, even where they have been excluded, such Afro-Colombians in Colombia, ${ }^{113}$ or to increase the amount of compensation they would get in comparison to the national reparation programme. ${ }^{114}$ There has been a symbiotic relationship in Latin America with national reparations programmes and the InterAmerican system, with them influencing each other on the scope of victims and appropriate measures.

It is easy to place blame for the lack of implementation at the door of a truth commission and its construction of recommendations. In Sierra Leone, the government rested the failure of reconciliation on the TRC for not developing a follow-up strategy, not securing sufficient financial support, and in raising expectations without any long-term planning. 115 However, this is not the mandate of truth commissions, it is the government who is responsible for delivering reparations. Even the legislation that designs the mandate of truth commissions can be vague as to the details in carrying out reparation, causing challenges in implementation. The Kenyan TJRC Act permits victims of gross violations of human rights to apply to the Commission for reparations. The Commission had no power to award or implement reparations, only to make recommendations on '(a) the basis and conditions upon which reparation may be granted; (b) the authority responsible for the reparation; and (c) measures that should be taken to grant urgent and interim reparation to victims.' 116 Reparations have not been dispersed to victims of the post-election violence in Kenya despite the recommendations of the TJRC, government directives and victim litigation. 117

Truth commissions rarely have implementation bodies, with the exception of the Rettig Commission in Chile, but even the delivery of reparation in Chile was through a separate administrative body, the CNRR (Corporación Nacional de Reparación y Reconcialiación). It can be undesirable for truth commissions to be

\footnotetext{
${ }^{113}$ Case of the Afro-descendant communities displaced from the Cacarica River Basin (Operation Genesis) v. Colombia. Preliminary Objections, Merits, Reparations and Costs. Judgment of November 20, 2013. Series C No. 270, para.470.

${ }^{114}$ See Case of the Río Negro Massacres v Guatemala, Preliminary Objection, Merits, Reparations, and Costs, Judgment of 4 September 2012, Series C No. 250, para.303-309.

115 R. FRIEDMAN, Competing Memories: Truth and Reconciliation in Sierra Leone and Peru, Cambridge (2017), p113.

116 Article 42(3), TJRC Act 2008.

117 Restorative Justice Fund not created 3 years after directive, Capital News, 19 March 2018.
} 
burdened with the technical and administrative process of identifying and delivering reparations to victims, as it may affect their capacity to uncover truth.118 Though it is worth remembering that without an implementation body and dependent on political generosity of the government, victims often have to force implementation through political pressure or the courts, which even them do not guarantee delivery by themselves.

\section{Reparations Without a Truth Commission}

There is no road map for transitional justice, the different measures of truth, justice and reparations are lights meant to guide the way forward through a dark past. Many countries have chosen not to establish a truth commission, but instead have created a reparations programme. In addition, having a truth commission and a reparations programme may not satisfy victims' needs for redress, who can continue to pursue through the courts their own vision of remedy. In the case of Colombia, the 2005 Justice and Peace Law provided a transactional arrangement for demobilising paramilitaries, in which they contributed information and assets for truth recovery and reparations in exchange for more lenient sentences under the auspices of a criminal justice dominated approach. 119 While this law focused on the responsibility of paramilitaries, neglecting the actions of state forces, this was in part remedied through the Victims' Restitution Law 2011. The subsequent peace process with FARC will see a further expansion of the reparation programme to victims of this group and others, as well as a truth commission and other measures.120

Transitional justice measures are meant to complement each other, one without the other can undermine the dual individual-societal dimensions embedded in each measure in dealing with the past. Reparations without truth-telling can hide away victims' harm from the public eye, with compensation being the manner in which the state tries to 'buy [their] silence or acquiescence'.121 In cases of disappearances, victims' families may not be satisfied with compensation, but want to know the circumstances around the disappearance and fate of their loved one, in the hope of

118 ORENTLICHER, E/CN.4/2004/88, 27 February 2004, para.19(b).

119 Ley de 975 (2005).

120 Final Agreement to end the armed conflict and build a stable and lasting peace, 24 November 2016.

121 Report of the independent expert to update the Set of Principles to combat impunity, D. ORENTLICHER, 18 February 2005, E/CN.4/2005/102, para.59(d). 
giving them a proper burial. 122 In Brazil, social movements in pursuing civil litigation in the absence of a truth commission eventually saw a reparations body to be established.123 Brazil had a range of compensation schemes that were made up of a 'series of unrelated laws and decrees', but not part of a comprehensive reparations programme.124 The detachment and privatisation of harm caused victims to pressure the government into establishing a truth commission to publicise the harm caused, in particular around torture, but only years after the events. Comparably, the Canadian Truth and Reconciliation Commission on the historic abuse of First Nations people in residential school followed on from a class action settlement, with its recommendations' focus on more symbolic measures and institutional reform to prevent repetition.125 Together these examples may reflect that there is a continuum of transitional justice measures. Perhaps for each context it is not formulaic as simply finding the truth first, then reparations in consequence to the findings, but instead being comprehensive and finding the best temporal fit to advance an issue. ${ }^{126}$

In a way, victims' use of civil litigation to claim compensation has been secondary to their goal of seeking accountability and acknowledgement. To give an example, in Brazil, victims of torture claiming against the head of the Centre for Operations for Internal Defence, or in Northern Ireland by victims of the Omagh bombing suing leaders in the Real IRA who were never prosecuted.127 The absence of a truth commission leaves the burden of uncovering the truth about the past on the shoulders of victims, who can try to pursue truth and reparations through civil litigation in courts or mobilise on the streets. Not all victims want reparations and truth. In Northern Ireland, injured victims have been advocating for a pension as a form of reparations, rather than truth. As one victim case worker noted that for those injured they were more concerned with 'improving their quality of life', than truth or

122 ORENTLICHER, E/CN.4/2005/102, para.63.

123 See C. MACDOWELL SANTOS, 'Transitional Justice from the Margins: Legal Mobilization and memory Politics in Brazil', in N. Schneider and M. Esparza, Legacies of State Violence and Transitional Justice in Latin America: A Janus-Faced Paradigm? Lexington (2015), at 37-72.

124 I. CANO and P. GALVÃO, Ferrera, p102.

125 Canada's Residential Schools: Reconciliation, The Final Report of the Truth and Reconciliation Commission of Canada, Volume 6, p223-241

${ }^{126}$ E. DALY, 'Truth Skepticism: An Inquiry into the Value of Truth in Times of Transition', International Journal of Transitional Justice, 2(1) (2008) at 23-41, p39-40.

127 SANTOS p61; and L. MOFFETT, Beyond Attribution: Responsibility of Armed Non-State Actors for Reparations in Northern Ireland, Colombia and Uganda, in N. GAL-OR, C. RYNGAERT, and M. NOORTMANN (eds.), Responsibilities of the Non-State Actor in Armed Conflict and the Market Place: Theoretical Considerations and Empirical Findings, Brill 2015, at 323-346. 
justice.128 For some victims acknowledgement and truth are more important, in that reparations are seen an insult to the memory of their loved one. For such individual truth and acknowledgement are more important, transitional justice mechanisms have ot be flexible to a certain level of choice for victims as whether or not they want to engage in them.

Reparations alongside or after a truth commission can promote better transparency and inclusion than previous awards. After the peace agreement in the Solomon Islands, compensation was distributed to those who lost economic opportunities and property, but lacked guidelines and transparency, resulting in corruption and failed to highlight the truth on the wider pattern of violations. The subsequent TRC recommended comprehensive reparations to a broader range of more serious violations, but has so far not received funding.129 Similarly the Moroccan Arbitration Panel while offering compensation to thousands of victims, was considered to have failed to uncover the truth and provide reparations to all victims who had suffered under the regime.130 As a result, the Equality and Reconciliation Commission (IER), was established to provide more comprehensive reparations and truth. Even with such measures, corruption can still be a substantial issue for any reparation programme with or without a truth commission. The benefit of a truth commission beforehand is that it can awaken society to the importance of delivering reparations to victims, and that the truth is not just empty words, but that it has real consequences for victims. 131

\section{Conclusion}

Truth commissions and reparations are often invoked on their basis to heal the wounds of the past and reconciliation. Informing expectations of these measures and ensuring their delivery is an important, if not vital part of the transition. The best we can expect between the two is that one opens the door for the other, facilitating society to accept that truth and reparations are necessary to heal the wounds of the past. While this is not to burden reparations with the expectations of reconciliation, it

128 Interview IR06, March 2017.

129 See N. DICKER, 'Development Aid for Reparations in the Solomon Islands', in R. JEFFERY (ed.), Transitional Justice in Practice: Conflict, Justice, and Reconciliation in the Solomon Islands, 203-228 (2017) at 203-228.

130 HAYNER p172.

131 THEIDON and LAPLANTE. 
can help to ease the differences amongst victims who are left to bear the burden of the past and the rest of society. At best, reparations can possibly address and acknowledge victims' suffering which in turn can open up space for them to engage with reconciliation. For victims reconciliation is an individual's choice, something that has to be voluntary and not the result of external pressure. The design and implementation of reconciliation is something best left to other social, moral, cultural or communal forces to broker, rather than a legalised top-down process by lawyers and by extension, reparations. Apologies are an important part of reparations and truth recovery with responsible actors acknowledging their wrongdoing, but they need to be carefully crafted in consultation with victims, so that it is meaningful to them and not merely a way for those responsible for causing them harm to justify their violence. $^{132}$

The global legacy of truth commissions is that they have helped to solidify the need for individual and community redress at the domestic level beyond uncovering the facts of the past. There remains a broad spectrum of practice and implementation around recommendations for reparations by truth commissions. That said, there is a consistency that a range of reparative measures, beyond compensation, need to be implemented by states to deliver remedies which are politically and symbolic imbued in promoting values of a transitioned society. In terms of achievements, there is a range of practice and experience to draw from the dozens of truth commissions to inform the establishment of new commissions. Truth commissions have helped to prioritise those who have suffered the brunt of violence, the hidden victims left out of the official state discourses on the past, encourage victim participation and cement the need for reparations. Yet there remain common challenges around implementation, such as in countries like Guatemala where ongoing violations continue to occur against indigenous and marginalised groups, where the partial implementation of reparations and completion of truth commission by themselves have not achieved a transformative agenda. Nevertheless there remains a strong bond between truth commission and reparations.

Truth commissions and reparations are two tools in the transitional justice toolkit, and while they can be complementary, they are designed to serve to some

\footnotetext{
132 See Queen's University Belfast's Human Rights Centre (HRC) and University of Ulster's Transitional Justice Institute (TJI) Submission on Reparations Issues pursuant to Article 75 of the Statute, 15 May 2015, ICC-01/04-01/07-3551, para.85.
} 
extent discrete functions. Recommendations for reparations by truth commissions provide a supportive and normalising function, which ultimately recognise the need to move beyond truth to alleviate the ongoing consequences of mass atrocities for victims. It needs to be remembered that although there are ambitious goals for such transitional justice mechanisms, reparations and truth commissions can only make modest contributions to reconciliation, building civic trust and the rule of law.133 In truth, the strength of truth commissions is their ability to "narrow the range of permissible lies',134 and of reparations, the provision of measures that can ease victims' suffering so that they may regain some quality of life and dignity.

133 L. MAGARRELL, 'Reparations for massive or widespread human rights violations: Sorting out claims for reparations and social justice', Windsor Yearbook of Access to Justice 22(1) (2003), 85-98, p94.

134 M. IGNATIEFF, The Warrior's Honor: Ethnic War and the Modern Conscience, Owl Books $1997, \mathrm{p} 174$. 